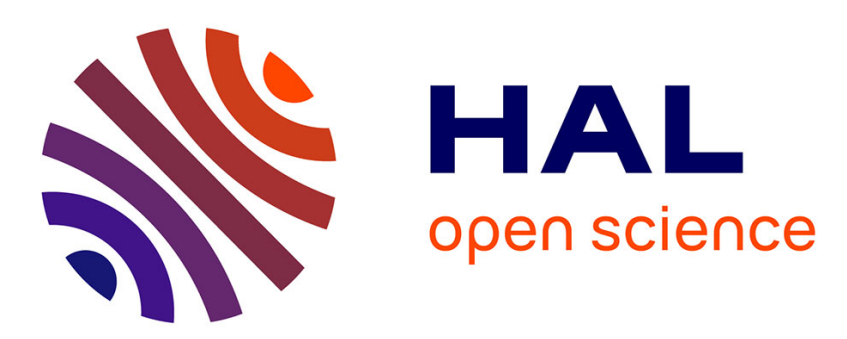

\title{
WHEN NUMBERS REPRESENTED POVERTY: THE CHANGING MEANING OF THE FOOD RATION IN FRENCH COLONIAL AFRICA
}

Vincent Bonnecase

\section{> To cite this version:}

Vincent Bonnecase. WHEN NUMBERS REPRESENTED POVERTY: THE CHANGING MEANING OF THE FOOD RATION IN FRENCH COLONIAL AFRICA. Journal of African History, 2018, Forum on Poverty, 59 (3), pp.463-481. 10.1017/S0021853718001111 . halshs-03508997

\section{HAL Id: halshs-03508997 \\ https://shs.hal.science/halshs-03508997}

Submitted on 4 Jan 2022

HAL is a multi-disciplinary open access archive for the deposit and dissemination of scientific research documents, whether they are published or not. The documents may come from teaching and research institutions in France or abroad, or from public or private research centers.
L'archive ouverte pluridisciplinaire HAL, est destinée au dépôt et à la diffusion de documents scientifiques de niveau recherche, publiés ou non, émanant des établissements d'enseignement et de recherche français ou étrangers, des laboratoires publics ou privés. 


\section{Version auteur de l'article}

BONNECASE, V. (2018). WHEN NUMBERS REPRESENTED POVERTY: THE

CHANGING MEANING OF THE FOOD RATION IN FRENCH COLONIAL AFRICA. The Journal of African History, 59(3), 463-48 


\title{
WHEN NUMBERS REPRESENTED POVERTY \\ THE CHANGING MEANING OF THE FOOD RATION IN FRENCH COLONIAL AFRICA*
}

Quand des chiffres en viennent à dire la pauvreté

Les significations changeantes de la ration alimentaire en Afrique coloniale française

\begin{abstract}
Vincent Bonnecase
Centre National de la Recherche Scientifique (CNRS), 'Les Afriques dans le monde', Bordeaux, France
\end{abstract}

Translated from the original French by Rachel Kantrowitz

Résumé. Cet article interroge l'évolution des savoirs sur l'alimentation en Afrique coloniale française des années 1920 au début des années 1950. Il porte plus spécifiquement sur les opérations de mesure de la ration alimentaire dans les colonies en questionnant les différentes significations qui leur ont été données : si de tels chiffres existent dès les années 1920 pour évaluer la ration des populations les plus utiles à l'économie impériale, ce n'est qu'après la Seconde Guerre mondiale qu'ils deviennent un élément de mesure des niveaux de vie à l'aune de normes universelles et en viennent à manifester la pauvreté relative de l'Afrique par rapport au reste du monde. Pareille histoire invite à réfléchir comment la pauvreté en Afrique est devenu un problème reconnu comme tel, en montrant qu'un tel processus n'a pas dépendu que de la réalité sociale ou des savoirs produits pour la circonscrire, mais aussi des modifications de sens que ces derniers ont subis.

ABSTRACT. This article examines the evolution of dietary knowledge in French colonial Africa, from the 1920 s to the early 1950s. More specifically, it focuses on efforts to quantify daily food intake by tracing the different meanings assigned to nutrition over time. While such statistics were used as early as the 1920 s to evaluate the food consumption of populations most useful to the imperial economy, it was only after the Second World War that they became a means of measuring living standards according to universal metrics. This history invites us to reflect on how poverty in Africa came to be recognized as a problem, by showing that such a process has neither been based entirely on social reality nor on the knowledge produced to delineate privation. Rather it also emerged from the changing set of meanings associated with this knowledge.

Keywords: poverty, colonialism, inequality, nutrition, West Africa, Equatorial Africa. 
The idea that Africa is poor - now commonplace — is nevertheless relatively recent. It emerged, in fact from international organizations in the aftermath of the Second World War, within the context of the standardization of knowledge about living conditions across the globe. It was presented as fact to a broader public a few decades later in the 1970s, when several African countries were struck by famine. ${ }^{1}$ Images of undernourished people, as well as statistics produced on hunger and malnutrition, played an important role in Africa's increasing association with poverty. The employment of numbers in this way thus first emerged in the second half of the twentieth century. In 1952, in its first report on 'the social situation across the world', the Economic and Social Council of the United Nations (UNESCO) assessed 'the energy content of the [nutritional] ration' in the Belgian Congo, Tanganyika, and French West Africa to be 1,930, 1,980, and 2,070 calories per capita per day, respectively. This marked the first time that an international report invoked statistics of this type to demonstrate the fact that living standards were quite low on the African continent. ${ }^{2}$ From this point forward, such declarations became commonplace. Indeed, every subsequent year, the United Nations Food and Agriculture Organization (FAO) released new statistics on the world food situation which, up to the present, has helped to reinforce the idea of Africa as the poorest continent in the world. ${ }^{3}$

However, food and nutritional statistics had been produced in Africa since the beginning of the twentieth century. As Michael Worboys has demonstrated, it was after the First World War that the first research was undertaken on nutritional conditions in African colonies. This, not coincidentally, occurred at the same time that nutritional science became a burgeoning field and when the colonial projects of mise en valeur required a healthy and large workforce. ${ }^{4}$ Several surveys, beginning in the 1920s, found evidence of food shortages in both the French and British empires. Alongside this knowledge that one could describe as intentional (because it was driven by the desire to know the nutritional status of populations, albeit with an eye towards their labor productivity), empirical knowledge was also created unintentionally, through routine administrative practices. In the period between the two world wars, labor recruitment services had precisely calculated the ration levels that were thought necessary to improve laborers' nutritional status and enable them to perform their required tasks. In this way, they became familiar with malnutrition and undernourishment in the colonies, without equating these realities with poverty.

This article asks how the broader problem of poverty in Africa has come to be defined by nutritional statistics. Specifically, this article will examine how nutritional rations were measured

\footnotetext{
${ }^{1}$ V. Bonnecase, La pauvreté au Sahel. Du savoir colonial à la mesure internationale (Paris, 2011).

2 UN Economic and Social Council (UNESCO), Preliminary Report on the World Social Situation and Living Standards in Particular (New York, 1952), 56.

${ }^{3}$ FAO, The State of Food and Agriculture (Rome, 2017)

${ }^{4}$ M. Worboys, 'The Discovery of Colonial Malnutrition between the Wars', in D. Arnold (ed.), Imperial Medicine and Indigenous Societies: Disease, Medicine and Empire in the Nineteenth and Twentieth Centuries (Manchester, 1988), 208-25.
} 
and interpreted from the 1920s to the 1950s. In French, the word ration means both the desired ration, that is, the quantitative and qualitative standards of what a good diet should be, and the actual ration or intake, that is, the evaluation of the nutritional levels of the population (or at least a subset of it). How did these figures come to highlight a gap between the desired and actual level of nutrition among different populations, and how did they become interpreted as proof of low living standards across the African continent?

Though this line of inquiry engages with a substantial existing literature, it proposes a new approach. Several works on hunger and malnutrition in colonial Africa have been based on intended knowledge, that is, knowledge that is produced explicitly to add to existing nutritional knowledge. The ultimate aim of these studies was to analyze what this type of knowledge meant, not only relating to the nutritional status of populations, but also about administrators' motives and methods. ${ }^{5}$ Fewer scholars have focused on unintended knowledge, such as that which resulted from physical measurements recorded as part of military recruitment or the compilation of statistics by agricultural extension services in an attempt to more accurately assess changes in living conditions in Africa. ${ }^{6}$ Here, I am concerned with a third option beyond the existing literature: examining the changing meanings that these types of knowledge had for their contemporaries, whether intended or not.

Such a perspective raises broader questions about the history of poverty statistics in Africa. Many scholars have shown how these exogenously-defined statistics have conditioned the understanding and treatment of poverty on the continent, disrupting endogenous conceptions of well-being in the process. ${ }^{7}$ Others, taking the numbers at face value, queried their ability to accurately measure poverty. However, in historicizing these figures, it is just as important to consider their political uses and degree of reliability as it is to analyze the changes in meaning that

\footnotetext{
5 V. Bonnecase, 'Avoir faim en AOF: Investigations et représentations coloniales (1920-1960)', Revue d'histoire des sciences humaines, 21 (2009), 151-74; C. Brantley, Feeding Families: African Realities and British Ideas of Nutrition and Development in Early Colonial Africa (Portsmouth, 2002); H. Moore and M. Vaughan, Cutting down trees: gender, nutrition, and agricultural change in the Northern Province of Zambia, 1890-1990 (Portsmouth, 1994); D. Simmons, 'Starvation Science from Colonies to Metropole', in F. Trentmann and A. Nützenadel (eds.), Food and Globalization (Oxford, 2008), 173-92; J. Tappan, The Riddle of Malnutrition: The Long Arc of Biomedical and Public Health Interventions in Uganda (Athens, OH, 2017).
}

${ }^{6}$ D. Eltis, 'Nutritional Trends in Africa and the Americas: Heights of Africans', Journal of Interdisciplinary History, 12:3 (1982), 453-75; A. Moradi, 'Towards an objective account of nutritional health in colonial Kenya: a study of stature in African army recruits and civilians, 1880-1980', Journal of Economic History, 69:3 (2009), 723-4; A. Nouschi, Enquête sur le niveau de vie des populations rurales constantinoises de la conquête jusqu'en 1919: Essai d'histoire économique et sociale (Paris, 1961).

${ }^{7}$ For further discussion of the categories of understanding of poverty see J. Guyer, 'Pauper, percentile, precarity: Analytics for poverty studies in Africa', Forum on Poverty, The Journal of African History, 59:3 (2018), pXX; M. Jerven, 'The history of African poverty by numbers: Evidence and vantage points', Forum on Poverty, The Journal of African History, 59:3 (2018), pXX; M. Jerven, Poor Numbers: How We Are Misled by African Development Statistics and What to Do about It (Ithaca, 2013); M. Jerven, Africa: Why Economists Get It Wrong (London, 2015). . 
they underwent. The exercise of colonial power has long been accompanied by significant statistical output in many domains. Yet only relatively recently did some of these figures became associated with the colonial population's standard of living and the ability of colonial governments to improve it. In a sense, these statistics have their own biography, which accounts for the different values and changes in interpretation associated with them over the course of their own lives. ${ }^{8}$

\section{RATION POLICIES IN THE INTERWAR PERIOD}

It was in the 1920s, when the field of nutritional science was rapidly growing, that the first studies were conducted examining the 'native ration' in Africa. These investigations were motivated mainly by concerns about production and output, in a context where the imperative of 'mise en valeur' required the 'development of the races in quantity and quality'. ${ }^{9}$ Though such studies can, in retrospect, be viewed as illustrations of pervasive poverty, this was not their primary meaning for those who originally interpreted the data. Until the early 1940s, nutritional statistics were rarely used to evaluate overall living conditions. Rather, they were more often employed to establish what the subsets of the population who were most useful to the imperial economy should be eating.

\section{What should workers eat?}

The assessment of humans' nutritional needs has a long history. As early as the nineteenth century, the minimum intake requirements of protein, fat, and carbohydrates were established. It dates back even further, to the eighteenth century, if we consider Antoine Lavoisier's first work on calories. ${ }^{10}$ However, it was not until the early twentieth century that such assessments became directly associated with measuring living standards. In his pioneering work on poverty, Benjamin Rowntree relied on caloric and protein requirements to establish his 'poverty line' in the city of York, England. ${ }^{11}$ By the end of the First World War, the discovery of vitamins had profoundly reshaped approaches to nutrition. ${ }^{12}$ Meanwhile, the Inter-allied Scientific Commission for Food Supply was the first to establish the 'optimal ration level' on an international scale, with the aim of planning food distribution in European countries and preventing poverty from causing political unrest. ${ }^{13}$ Subsequently, the International Labor Organization and the Health Committee of the

\footnotetext{
${ }^{8}$ My use of the term biography is influenced by I. Kopytoff, 'The cultural biography of things: commoditization as process', in A. Appadurai (ed.), The Social Life of Things: Commodities in Cultural Perspective (Cambridge, 1986), 64-94.

${ }^{9}$ A. Sarraut, La mise en valeur des colonies (Paris, 1923), 95.

${ }^{10}$ A. Lavoisier, Traité élémentaire de chimie (Paris, 1789). See also, 'Mémoire sur le degré de force que doit avoir le bouillon, sur sa pesanteur spécifique et sur la quantité de matière gélatineuse solide qu'il contient' (Paris, 1783).

11 B. Rowntree, Poverty: A Study of Town Life (London, 1902), 102.

12 R. Smith, 'The emergence of vitamins and bio-political objects during World War I', Studies in History and Philosophy of Biological and Biomedical Sciences, 40 (2009), 179-89.

${ }^{13}$ N. Cullather, 'The Foreign Policy of the Calorie', American Historical Review, 112: 2 (2007), 337-64.
} 
League of Nations revised the definition of the optimal diet several times. These revisions were part of an effort to evaluate the effects of the Great Depression on the living conditions of the working classes. ${ }^{14}$ Measuring the quantitative and qualitative inadequacies of food intake thus became increasingly linked to the question of poverty and the social policies targeting industrialized countries in the interwar period. ${ }^{15}$

Most of the African continent thus remained on the margins of these developments. Instead, here the development of nutritional science pertained mostly to workforce management. After the First World War, a shortage of labor, in both quantity and quality, came to be seen as the primary obstacle to the productive use of the African colonial territories. Albert Sarraut, the French minister of the colonies, invested in nutritional and sanitary measures to produce a healthier and stronger workforce, which he saw as a necessary element of his desire to pursue the rational economic exploitation, or mise en valeur, of the colonies. The Governor General of French West Africa (AOF), Jules Carde would link Sarraut's imperative to 'mettre en valeur' to the regenerative racialized injunction to 'faire du Noir', or to increase the African population. ${ }^{16}$ In the words of the manager of a concessionary company, the challenge was 'to provide sufficient calories to the worker in order to regain a reasonable portion of it [that energy] in the form of labor'. ${ }^{17}$ The intake of animal-based protein came to be seen as a particularly important factor in fortifying the 'African races'. As a doctor specializing in 'exotic pathologies' wrote in 1925:

The possibility of improving certain races through nutrition has long been demonstrated. [...] It is universally recognized that the most enterprising, most aggressive people are big meat eaters. [...] Likewise, a diet that is too exclusively vegetable-based clearly weakens their constitution [...] Therefore one should stimulate 'the blacks' by introducing animal products into their diet, that would have a positive effect on their character and activities. ${ }^{18}$

This concern for workers' diets resulted in a more comprehensive codification of the rations allocated to workers. Until the 1910s, only a few local bylaws specified what labor recruits needed to eat. ${ }^{19}$ By the 1920 s, the requisite ration level was standardized in each colony. Several 'ration

\footnotetext{
14 'Report on the Physiological Bases of Nutrition', Quarterly Bulletin of the Health Organization of the League of Nations, IV (1936), 391-416.

15 International Labor Office, Workers' Nutrition and Social Policy (Geneva, 1936).

16 On both idiomatic phrases 'la mise en valeur' and 'faire du Noir,' see A. Conklin, A Mission to Civilize: The Republican Idea of Empire in France and West Africa, 1895-1930 (Stanford, 1997), 220.

17 Centre des Archives d'outre-mer, Aix-en-Provence (CAOM) GG-AEF-3H38, lettre du directeur de la Compagnie lyonnaise de l'AEF à l'inspecteur général des travaux publics, 26 décembre 1923.
}

18 A. Gauducheau, 'Comment combler le déficit alimentaire des indigènes dans les colonies françaises', Annales de médecine et de pharmacie coloniales, 23 (1925), 294-5.

19 H. d'Almeida Topor, 'Travail et alimentation. La ration des salariés en Afrique occidentale française dans la première partie du XXe siècle', in H. d'Almeida-Topor, M. Lakroum et G. Spittler (eds.), Le travail en Afrique noire. Représentations et pratiques à l'époque contemporaine (Paris, 2003), 207-13. 
types' were delineated according to people's eating habits, local production, and the opportunities available for importing food: there were diets based on millet, corn, or rice in the Sahel and cassava, yams, bananas, or rice further south. Each ration type specified a corresponding amount of fats to be consumed (in the form of palm oil or peanuts) and animal protein (in the form of fish or beef, gazelle, or, in some cases, elephant) ${ }^{20}$ Distinctions were also made according to whether workers could travel to nearby villages to buy fresh produce 'essential for providing vitamins' ${ }^{21}$

These ration types, however, only existed on paper as official categories. They were seldom followed in practice, according to the reports of colonial doctors. In the most extreme cases, such as that of the Congo-Océan railway, there were 'famished workers in a state of deplorable physical deterioration [...] that can only by explained by a state close to starvation'. ${ }^{22}$ On the railway construction sites, ration levels frequently gave rise to disputes between labor services that cited the cost of workers on the one hand, and doctors who referred to nutritional science on the other. In 1929, as the Inspector General of Health Services of French Equatorial Africa (AEF) explained:

It is desirable to provide as often as possible a ration in which the carbohydrate provision is mixed [...], given the low caloric content of potatoes $(1,100 \mathrm{gr} .=1,641 \mathrm{cal}$.$) , bananas$ $(1,100$ gr. $=1,641)$. cal. $)$, yams $(1,100$ gr. $=1,465$ cal. $)$ as compared to rice $(750$ gr. $=2,686$ cal.)[...]. The substitution of 200 grams of groundnuts for 200 grams of fish should be increased to two days per week, although the caloric content of 200 grams of peanuts is greater than that of 200 grams of fish $(1,174$ / 518), given the large difference in the amount of protein (fish: 106.2 / peanuts: 12.7). For the same reasons, approximately 200 grams of potatoes, and not 100 grams [...], should be substituted for 70 grams of rice (70 grams of rice $=253 \mathrm{cal} / 100$ grams of potatoes $=123 \mathrm{cal}.)^{23}$

A similar call for relying on science to improve workers' diets also emanated from companies producing food supplements: this was the case of the Société française des produits alimentaires azotés which, in the 1920s, claimed to be able to solve 'the problem of colonial nitrogen supply' thanks to a product containing 'all the necessary amino acids [...], minerals [...] and vitamins essential for growth' ${ }^{24}$ Made from peanut and cassava, this product came in the form

20 CAOM GG-AEF-3H40, mission d'inspection de la main d'œuvre, 'Dossier sur le fonctionnement du service de main d'œuvre en AEF', 1925; CAOM GUERNUT50, Commission Guernut, 'Documentation sur 1'application de la règlementation du travail indigène en AOF en 1932', 1938.

${ }^{21}$ CAOM GG-AEF-3H38, Gouvernement général de l'AEF, 'Note sur la comparaison entre les types A, B et C de la ration dans l'arrêté du 6 avril 1926', 1926.

22 CAOM GG-AEF-3H38, rapport du chef du service médical du chemin de fer Congo-Océan sur la ration des travailleurs, 1924.

23 CAOM GG-AEF-3H38, Inspection général des services sanitaires de l'AEF, 'Note au sujet de la composition de la ration des travailleurs du CFCO', février 1929.

24 CAOM GG-AEF-3H38, Société française des produits alimentaires azotés, 'De l'alimentation de l'homme. La ration d'azote indispensable', 1928. 
of a biscuit or soluble substance to be added to cooked food. It lent itself to a 'standardized calculation of rations' since it 'always [contained] the same proportion of nitrogen, amino nitrogen, mineral salts and sodium chloride'. ${ }^{25}$ Used by the administration in several colonies in AEF in the 1920 s, it was finally abandoned in the early 1930 s, due to its high cost. ${ }^{26}$ In any case, this product was used not as a weapon in the fight against poverty, but rather to improve the output of African workers.

In this way, nutritional science helped to shape the contours of what constituted a good diet for the subset of the population deemed useful for the colonial project: mostly, in other words, those recruited into the workforce. ${ }^{27}$ Even so, nutritional research led to the recognition - timely yet almost incidental to the original aim of nutritional studies - of widespread undernourishment and malnourishment among the general population. In the 1930 s, recruiting agents rarely failed to point out that workers were 'copiously fed' compared to their 'standard fare' which was characterized by many deficiencies. ${ }^{28}$ In 1931, a doctor who studied the diets of African soldiers and workers wrote:

The native in his village is undernourished. On joining his regiment, he voraciously throws himself into his large and appetizing ration. His body is quickly overwhelmed by this rare influx. [...] The daily ration is to be carefully applied gradually bringing the intake up to its desired amount, while at the same time slowly and gradually, the native becomes accustomed to the work. ${ }^{29}$

In the end, prescriptions related to the 'normal ration' for workers implicitly assumed the existence of an 'abnormal ration', insufficient and lacking, which colonial administrators admitted to be the general lot of the general population. Yet this abnormality was less frequently measured than the real problem of the nutritional requirements needed to maintain a strong workforce.

\footnotetext{
${ }^{25}$ CAOM GG-AEF-3H40, lettre du directeur de la Société française des produits alimentaires azotés au secrétaire général de l'AEF, 2 mars 1931.

26 CAOM GG-AEF-3H49, lettre du gouverneur général de l'AOF aux gouverneurs des colonies, janvier 1933. The properties of this product, developed by the food industry, easy to use and made from peanuts, were strikingly similar to the 'Ready-to-Use Therapeutic Foods' that would be developed much later in the fight against malnutrition in poor countries. The best known of these foods is Plumpy Nut, developed in the 1990s. See J.-F. Caremel, 'Les aliments thérapeutiques prêts à l'emploi et la "pharmaceutalisation humanitaire" de la malnutrition au Sahel' in M. Badji and A. Desclaux, Nouveaux enjeux éthiques autour du médicament en Afrique (Dakar, 2015), 231-46.

27 This also concerned the military, even if their ration was less open to debate within the colonial services. See H. Gravellat, 'Note sur l'alimentation du tirailleur en Afrique occidentale française', Annales de médecine et de pharmacie coloniales, 25 (1927), 81-102.

${ }^{28}$ CAOM GG-AEF-2H28, Berbérati Subdivision (Oubangui-Chari), rapport périodique sur la main d'œuvre, 1934.

${ }^{29}$ J.-E. Martial, 'Contribution à l'étude de l'alimentation du tirailleur sénégalais en Afrique occidentale française', Annales de médecine et de pharmacie coloniales, 29 (1931), 532.
} 


\section{What did the general population eat?}

Food in the interwar period, however, was not only an economic issue, from the colonial administration's point of view. It was also an issue of legitimization: administrators regularly invoked the idea that colonization should improve people's living conditions in order to justify the colonial project. In the realm of food, this imperative guided such initiatives as the creation of reserve granaries in villages. ${ }^{30}$ Yet this justification garnered little by way of quantitative research: nutritional statistics, and numerical figures more generally, were not used to measure living conditions in Africa until the late 1930s.

On 16 January 1925, the biologist Émile Roubaud presented a 'Report on the question of the insufficient nutrition of the indigenous people in French territories' before the Academy of Colonial Sciences in Paris. His report began:

The question of food, or rather of undernourishment of the indigenous populations in our colonies, deserves our urgent attention [...]. It is not an exaggeration to say it is a fundamental question of latent physiological misery linked to one of the main causes of the depopulation observed in most overseas territories. Based on the survey carried out by the Academy of Colonial Sciences, it follows that our indigenous populations rarely find, in the food resources upon which they rely, sufficient nutrients for a healthy diet. ${ }^{31}$

The study Roubaud cited was a compilation of medical observations and proposals to improve the situation. Such improvements, Roubaud made clear, responded to an economic rationale, since the 'populations regenerated by food and their well-being [...] will largely pay back the care they have been given through more efficient labor.' Yet it also appealed to a moral imperative because 'France owes it to herself [. . .] to make the necessary sacrifices to safeguard the primitive races of whom she assumes the guardianship' ${ }^{32}$ These concerns were not unique to the French colonies. It was also in 1925 that the first survey of diets in British Africa began, in Kenya, led by John Boyd Orr and John Gilks. ${ }^{33}$ These various studies reflected, as John Iliffe has noted, a shift in the way the colonial administrations understood food in their territories. Instead of famine, which had been the primary concern in the first decades of colonization, they now also focused on malnutrition. ${ }^{34}$

A few months after Roubaud's speech in Paris, Édouard Daladier decided that, in each colony, 'a chemistry laboratory should be dedicated to the study of the native ration [...] and

\footnotetext{
30 'Avoir faim en AOF', 154-8.

31 CAOM AGEFOM 940, Académie des Sciences coloniales, 'Rapport sur la question de l'insuffisance alimentaire des Indigènes dans les possessions françaises', 1925.

${ }^{32}$ Ibid.

${ }^{33}$ C. Brantley, 'Kikuyu-Maasai Nutrition'.

${ }^{34}$ J. Iliffe, The African Poor: A History (Cambridge, 1987), 160.
} 
investigate ways to remediate any nutritional deficiencies that they find'. The Minister of the Colonies elaborated:

In certain countries, there are deficiencies in specific key minerals such as calcium, sodium, phosphate, or iron. Elsewhere, it could be fats, carbohydrates, or vitamins that are lacking. On the other hand, the importance of nitrogenous elements is considerable, perhaps even moreso in terms of their quality than their quantity. In addition to protein-rich foods which allow growth, nitrogenous foods ensure healthy tissues. ${ }^{35}$

These ministerial instructions, while encouraging the collection of observations throughout the French empire, did not give rise to projects concerned with the overall diet of African populations. The only exception was Togo where a colonial military pharmacist, Auguste Cheyssial, carried out a study. Cheyssial attempted to examine 'daily consumption' among each of the seven ethnicities in Togo, presupposing a similar level of nutrition among individuals of the same ethnic group. ${ }^{36}$ The description of diets was quite precise: in the administrative district [cercle] of Lomé, individuals consumed ' 375 grams of sauce containing two fish, palm oil, salt, and pepper; 1,200 grams of cassava; and 1220 grams of white corn meal'. Once he had made his calculations, almost all of average intakes were higher than the assumed levels and some were as high as 6,505 calories. Only one group, the 'Lossos of Sokodé district', described as a 'poor race with low fertility rates', appeared to be insufficiently nourished, with an intake of 2,529 calories. Cheyssial concluded that 'the natives of Togo [...], far from being undernourished, are on the contrary overfed, because the caloric value of their daily rations exceeds, and sometimes by a significant amount, the normal amount of 3,500 calories'. ${ }^{37}$

Cheyssial's study on daily rations was the only one of its kind conducted in the French empire before the early 1930s. In 1932, Georges Hardy, director of the National School of Overseas France, and Charles Richet, professor of medicine, synthesized the knowledge accumulated since the ministerial directive of 1925 by publishing a book on 'native food in the French colonies'. From the outset, this book was presented not only through a moral lens, but also through an economic one, since 'to exert the considerable effort required of them, the indigenous populations need the muscular vigor that only a good diet could provide'. ${ }^{38}$ The authors indicated that a significant proportion of the indigenous population was 'insufficiently nourished'. 39

\footnotetext{
35 CAOM AGEFOM940, ministère des Colonies, 'Instruction relative à l'étude hygiénique de la ration alimentaire des populations indigènes', 4 avril 1925.

${ }^{36}$ Research conducted on 'tribal diets' in Kenya at this same time was also based on this assumption. See Brantley, 'Kikuyu - Maasai Nutrition', 50.

${ }^{37}$ A. Cheyssial, 'Étude de la ration alimentaire des indigènes du territoire du Togo', Annales de médecine et de pharmacie coloniales, 29 (1935), 503-16.

38 G. Hardy and C. Richet (eds.), 'Préface' in L'alimentation indigène dans les colonies françaises, protectorats et territoires sous mandats (Paris, 1933), 6.

${ }^{39}$ Ibid. 9.
} 
According to their overview of the situation, food appeared to be 'sufficient' in Togo and along the Somali Coast, 'insufficient in some districts' in AOF and Cameroon, and 'extremely insufficient' in AEF. ${ }^{40}$ Yet with the exception of Togo, none of these conclusions were based on numbers. While the authors referred to statistical standards for what a balanced diet should consist of, they had no data to assess whether these standards were actually met. They thus concluded that it would be 'desirable that the excellent work of Cheyssial [...] be undertaken in the [other] colonies'. ${ }^{41}$

This same recommendation was repeated in the mid-1930s, specifically within the context of the development of nutritional research internationally. As the effects of the economic crisis on the nutritional conditions of populations became a cause for increasing concern, a 'Technical Commission on Food' was created within the League of Nations in $1935 .{ }^{42}$ This commission called for an increase of nutritional surveys, as well as the standardization of research methods so that the results would be comparable across countries. ${ }^{43}$

This increased interest in nutritional research had a modest degree of impact on the African continent. In British Africa, one study was carried out by Audrey Richards in Northern Rhodesia, beginning in 1932 and continuing into the second half of the decade. ${ }^{44}$ Benjamin Platt conducted another investigation in Nyasaland. ${ }^{45}$ Meanwhile, in the Gold Coast, Cicely Williams's 1935 analysis of a disease she named kwashiorkor sparked international scientific debate. ${ }^{46} \mathrm{~A}$ 'Committee on Nutrition', created in 1936 by the British Colonial Office, collected data in the various colonial territories and published, three years later, a report on 'Food in the colonial empire' which traced changes in how the problem had been understood. ${ }^{47}$ As Frederick Cooper has written, British administrators 'blame[d] the dietary deficiencies of the colonial people on [. . .] the fact that the standard of life was too low, that is, people ate badly because they were poor.' 48

\footnotetext{
${ }^{40}$ Ibid. 40.

${ }^{41}$ Ibid. 207.

${ }^{42}$ League of Nations, The problem of nutrition: Vol. 1 (Geneva, 1936), 58.

43 Technical Commission on Nutrition, Guiding principles for studies on the nutrition of populations (Geneva, 1939).
}

${ }^{44}$ A. Richard, Hunger and work in a savage tribe: a functional study of nutrition among the Southern Bantu (London, 1932); A. Richard, Land, Labor, and Diet in Northern Rhodesia: The Economic Study of the Bemba Tribe (London, 1939).

${ }^{45}$ B. Platt, Report of the Nyasaland Nutrition Survey, 1938-39 (London, 1939).

${ }^{46}$ C. Williams, 'Kwashiorkor: A nutritional disease of children associated with a diet diet', Lancet, 226 (1935), 11512.

\footnotetext{
${ }^{47}$ Economic Advisory Council, Nutrition in the Colonial Empire (London, 1939).

48 F. Cooper, Decolonization and African Society: The Labor Question in English and British Africa (Cambridge, 1996), 63.
} 
After the victory of the Popular Front in 1936, a similar movement took shape in French Africa. The new government launched a major 'survey of the needs and legitimate aspirations of the people living in the colonies' in 1937. According to the head of the commission of inquiry, Henri Guernut, the study aimed to 'thoroughly research exactly what the social status and living standards are of the natives in order to further accelerate their improvement'. ${ }^{49}$ Food was the first major subject of the study: questionnaires were mailed out to each district of each colony, with instructions to select a socioeconomic cross-section of families that were 'rich,' 'comfortable', and 'poor', to weigh the foods that they ate, and send the results to chemists who would calculate the 'dietary value'. ${ }^{50}$ These instructions led to a significant collection of information in French Africa, but not a single administrator delivered all of the figures requested of them. The only exception was a study of forty families' meals, conducted in Chad in 1938 by a pharmacist, Paul Créac'h: a quarter of the rations calculated were under 2,400 calories per person per day, the lowest was 907 calories. ${ }^{51}$ In the other studies, the researchers simply noted the daily number of meals, food consumed and, sometimes, the amount of food expenditures. Such work helped to highlight food disparities between 'rich', 'comfortable', and 'poor'. Contrary to the stated objectives, however, the study did not evaluate nutritive value. ${ }^{52}$

In addition to being very limited in scope, the nutritional information collected in Africa did not circulate widely in European metropoles or in international organizations. In 1937, the Scientific Society of Food Hygiene organized an International Nutritional Congress in Paris, which, for the first time, aimed at taking stock of existing research on nutritional conditions across the globe. ${ }^{53}$ The central focus of the discussion was industrialized countries. One panel was dedicated to the colonies, but it barely featured statistics. In the Belgian Congo 'black people' appeared 'undernourished' to such an extent that it was impossible to discern to what extent 'any study of the living conditions such as we conceive of them in Europe, with the quantitative aspect that implies, could be achieved. ${ }^{54}$ In the Italian colonies, the daily caloric intake ranged from 'between 2,000 and 2,500 calories' according to a study conducted among families in Somalia, but

\footnotetext{
${ }^{49}$ National Archives of Senegal, Dakar (ANS) 17G252, lettre du président de Commission d'enquête dans les territoires d'outre-mer au gouverneur général de l'AOF, 9 février 1938.

50 National Archives of Mali, Bamako (ANM), NI 1D2026, Commission d'enquête dans les territoires d'outre-mer, 'Enquête sur l'alimentation des indigènes', 30 décembre 1937.

${ }^{51}$ Paul Créac'h, Aliments et alimentation des indigènes du Moyen-Tchad (Afrique équatoriale française) (Marseille, 1941). Créac'h first conducted this research for his thesis in pharmacy.

52 CAOM GUERNUT 100, Commission Guernut, 'Enquêtes n $1 \mathrm{C}$ sur l'alimentation des indigènes', 1937-1938. For more on these surveys, see Bonnecase, La pauvreté au Sahel, 52-66.

53 Created in Paris in 1904, during its first decades of existence this scientific society devoted itself to the principles of what it termed 'the rational diet of man' before focusing on food conditions around the world in the 1930s.

${ }^{54}$ Société scientifique d'hygiène alimentaire, La science de l'alimentation en 1937, III (Alençon, 1937), 6.
} 
'a definitive judgement [...] could not be formulated'. ${ }^{55}$ As for French Africa, 'people belonging to the black race' appeared to be 'well-nourished on the outskirts of the forest' and 'undernourished in the equatorial forests' of AEF. In AOF they 'eat their fill' despite a 'protein deficit', though these assertions about AOF and AEF were not supported by numerical data. ${ }^{56} \mathrm{By}$ comparison, they were more statistics available about the nutritional conditions of the workingclass populations in European and North American countries. Indeed, by the end of the 1930s, the League of Nation's Technical Committee on Nutrition had gathered nutritional statistics according to particular groups - the 'unemployed', 'workers', 'blacks', and 'elderly' — from a range of industrialized countries. ${ }^{57}$

As has been shown, even though significant studies were carried out on nutritional conditions in French Africa in the 1920s and 1930s, few were used to evaluate living conditions, as they were in Europe and North America during the same period. Even fewer still were studies that made use of this data to make arguments about poverty. Significantly, though international organizations were concerned with countries experiencing hunger and malnutrition, until the early 1940s Africa was less commonly associated with these issues than were Russia or Eastern Europe. ${ }^{58}$

\section{HUNGER IN AFRICA THROUGH THE LENS OF UNIVERSAL STANDARDS}

Things changed after 1945. In the context of a crisis of colonial legitimacy, the question of the living conditions of colonized populations, and especially their nutritional levels, provoked both international and local debates. So, too, did new studies which highlighted major nutritional problems in Africa. Data on nutritional rations in Africa thus emerged, among other statistics, as indicators of a relative poverty that affected this continent more profoundly than the rest of the world. Nevertheless, this change was not a natural consequence of the production of a new statistical knowledge alone. Rather, it was largely due to the political logic of inclusion within a singular referential space that altered the meaning of statistics produced about the French empire.

\section{The comparisons that statistics allowed}

The increased salience of the meaning attributed to food and nutritional statistics in postwar Africa should be understood in relation to two parallel dynamics. The first was the work of UN organizations, which produced new norms for the assessment of living standards, while subjecting

\footnotetext{
${ }^{55}$ Ibid. 158.

56 Ibid. 119, 125.

${ }^{57}$ F. McDougall, 'Food and welfare: League of Nations studies of nutrition and national economic policy' (Geneva, 1938).

58 On the place of Russia in social imaginaries of hunger during the interwar period, see F. Kurasawa, 'The making of humanitarian visual icons: on the 1921-1923 Russian famine as foundational event', in J.C. Alexander, D.M. Bartmanski, and B. Giesen (eds.), Iconic Power: Materiality and Meaning in Social Life (Basingstoke, 2011), 67-84.
} 
colonized populations to the same statistical framework as the 'civilized world'. ${ }^{59}$ The second was the implementation of social policies under the pressure of increasing popular mobilization in French Africa.

In 1943, US President Franklin Roosevelt convened a 'Conference on food and agriculture' in Hot Springs, Virginia. This conference, gathering together delegations from most allied countries, laid the foundation for a new international organization dedicated to agriculture and food. One of the 37 recommendations that was adopted stipulated that the future Member States should produce periodic reports on the state of nutrition in their own countries, but also 'those for which they are responsible'. It was thus specified during the first conference of the FAO, in October 1945:

In order to draw accurate conclusions, the reports should be comparable, from one year to the next in the same country, as well as across countries in the same year. In other words, the reports must be conceived along the same lines, exactly identical, drawn up according to the same methods, to allow for conclusions of the same order. [...] For developing countries, the need for uniformity that allows for comparison is even more important. ${ }^{60}$

This recommendation was indicative of the new cognitive framework within which hunger began to be understood after the war: food conditions around the world needed to be conceived of as being measurable and comparable. Such a perspective had been essentially confined to the 'populations of European civilization' in the interwar period, as if 'the Bosphorus was then the limit of the intellectual horizon' ${ }^{61}$ Yet from 1945 onwards, this horizon had extended to extraEuropean worlds.

Admittedly, Africa was still far from being at the center of this new conception of hunger in the immediate aftermath of the war. European countries, most of which were still subject to rationing, had many displaced or impoverished people suffering from serious nutritional problems themselves. ${ }^{62}$ The FAO thus considered the entire world to be in a situation of scarcity. Indeed, the FAO spoke of a 'world food crisis' until the late 1940s ${ }^{63}$ But this 'entire world' now also included Africa, whose nutritional conditions appeared on the agenda of the FAO's very first

59 R. Horvath, 'The Concept of International Statistics and Its Historical Evolution', International Journal of Statistics, 40: 3 (1972), 289.

${ }^{60}$ CAOM 1AFFPOL356, FAO 'Rapport préliminaire sur un projet de canevas unique pour l'établissement du rapport annuel dans les pays à développement retardé', 1945.

${ }^{61}$ FAO, The State of Food and Agriculture: Review of a Decade and Outlook (Roma, 1955), 18-20.

62 See Jane Guyer's contribution to this forum on the imaginaries of hunger and poverty in postwar Europe. J. Guyer, 'Pauper, percentile, precarity: Analytics for poverty studies in Africa', Forum on Poverty, The Journal of African History, 59:3 (2018), pXX.

${ }^{63}$ FAO, The State of Food and Agriculture. Review of a Decade and Outlook (Rome, 1955), 18-20. 
conference. ${ }^{64}$ As worldwide agricultural and food imbalances inherited from the war dissipated, the international focus on Africa increased. In 1949, the first international conference specifically devoted to food and nutrition in sub-Saharan Africa was held in Dschang, Cameroon. ${ }^{65}$ Two years later, in the first book written on world hunger, Brazilian geographer and nutritionist Josué de Castro, a member of the FAO Executive Board, devoted several chapters to Africa, which he described as 'a continent of the starving, all of it'. ${ }^{66}$

This growing attention to hunger in Africa was part of a broader examination of living standards around the world, of which food was considered to be an essential component. One of the principal activities of the new UN organizations was to establish criteria for the measurement and comparison of living conditions from one country to another. In 1948, the FAO established a 'Committee of Caloric Requirements' to update prewar standards, which had been 'mainly applied to Western countries'. ${ }^{67}$ In 1949, the United Nations General Assembly asked the Economic and Social Council (ECOSOC) to study 'the possibility of drafting a general report on the international cultural and social situation'. ${ }^{68}$ This led, in 1952, to the publication of the first 'Preliminary report on the world social situation, with special reference to standards of living', the objective of which was to propose 'as many quantitative indices as possible on needs whose existence is universally recognized' and to participate in a new 'fight against poverty' at the international level. Among these indicators was 'the energy and protein content of the per capita food ration' ${ }^{69}$ One year later, the Secretary-General of the United Nations formed a Committee of Experts charged with reflecting on 'the definition and evaluation of living standards from an international point of view.' Health and nutritional conditions were the first issues to be considered. In order to evaluate living standards, the Committee recommended in particular focusing on 'national food supplies [...] compared to caloric needs' while conceding that availability did not indicate anything about the 'effective food intake'. ${ }^{70}$

The renewed salience of the ration in the aftermath of the war was also part of a second, more local dynamic. At the time, French Africa experienced major labor strikes, most importantly in Dakar in 1945-1946 and along AOF's railroads in 1947-1948. The main demand of the strikers was securing African workers the same status as their metropolitan counterparts. As Frederick

\footnotetext{
${ }^{64}$ CAOM 1AFFPOL356, ministère de la France d'outre-mer, 'Rapport sur la conférence de l'ONU pour l'agriculture et l'alimentation', octobre 1946.

${ }^{65}$ Inter-African Conference on Food and Nutrition, Dschang, Cameroon, 3-9 October 1949 (Paris, 1951).

66 J. de Castro, The Geography of Hunger (Boston 1952 [1951]), 208.

${ }^{67}$ FAO, 'Calorie Requirements: Report of the Committee on Calorie Requirements', Nutritional Studies, 5 (1950).

${ }^{68}$ United Nations General Assembly Resolution No. 179-III of 13 May 1949.

${ }^{69}$ Preliminary report on the world social situation, 1, 3, 56.

70 CAOM BIB-SOM BR11715, United Nations, 'Report on the definition and assessment of living standards from an international point of view', June 1953.
} 
Cooper has explained, the labor unions used the assimilationist rhetoric of French imperialism to demand the introduction of the same payscale, the same benefits and, more broadly, the same living conditions within the empire. ${ }^{71}$ These social struggles went hand in hand with a reconsideration of the nutritional conditions in the colonies. In 1946, the 'Commissions for the study of living standards', comprised of representatives from both the administration and trade unions, were established in AEF and AOF to define a 'minimum subsistence-level' from which the workers' salary would be set. Notably, most of this 'minimum' was based on the 'required food ration.' According to the specifications of the Commission for the Study of Living Standards in AOF:

In the field of nutrition, we must start from the number of calories needed each day to ensure the subsistence of the individual. To determine these figures, one can use studies [...] carried out by Pierre Richet titled 'Native food in the French colonies'. Based on this, officials established that the number of calories needed per day should be set at 2,700 calories. $^{72}$

The Commission used Pierre Richet's figures from 1932, but slightly modified their meaning. ${ }^{73}$ It was no longer a question of ensuring that populations, while being immune from hunger, have the necessary number of calories to perform the tasks required by colonial development; it had become a question of ensuring the right of the salaried workers to access a 'minimum subsistence level' below which the basic needs were not satisfied ${ }^{74}$.

This shift invested nutritional statistics with new political value: they provided the justification for social demands, in particular for African labor unions. In 1949, the AOF's Union des syndicats confédérés submitted a 'revised table of the minimum subsistence levels' to the administration, arguing that:

The modifications made to it are [...] due to the need to compensate for the high proportion of fat that the two-and-a-half liters of oil contributes per month with foods containing a high proportion of carbohydrates (sugar, semolina, millet) in order to approximate as much as possible the ideal proportion whereby carbohydrates, proteins and lipids should represent at least $66 \%, 12 \%$, and $22 \%$ of the total calories, respectively. The latter corresponds to the recommended intake of 3,025 calories per day. ${ }^{75}$

71 F. Cooper, 'Labor, Politics, and the End of Empire in French Africa', in Colonialism in Question: Theory, Knowledge, History (Berkeley, 2005), 204-30.

72 ANS 17G175, ANS 17G175, Gouvernement général de l'AOF, 'Étude relative à un calcul sommaire du coût de la vie pour les indigènes', 1946.

${ }^{73}$ G. Hardy and C. Richet (eds.), L'alimentation indigène dans les colonies françaises.

${ }^{74}$ See Wayne Dooling's contribution to this forum, discussing the ways in which poverty and worker's wages were linked in the specific context of postwar Cape Town. W. Dooling, 'Poverty and respectability in early twentiethcentury Cape Town', Forum on Poverty, The Journal of African History, 59:3 (2018), pXX.

${ }^{75}$ ANS 1H90, Union des syndicats confédérés, 'Rapport sur le salaire minimum du manœuvre ordinaire à Dakar', 1949. 
On the other hand, the administration could also make use of scientific studies of the ration to quell labor union demands. In 1950, the General Inspector of Labor of the French Congo, confronted with the demands of students studying at the police academy, indicated that 'the ration allotted at the police school of Brazzaville' was 4,098 calories, a level 'higher than the needs of the students since a daily diet of 3,300 calories is considered sufficient for individuals engaged in hard labor' ${ }^{76}$ Nutritional specialists were at times called upon to respond to local disputes. In 1954, in response to a request for review filed by the railway unions in the Benin-Niger region, a nutritionist concluded that 'the requested caloric levels of the ration did not correspond to the 'level of an average worker' and that the current 'protein ration had been miscalculated' since 'we have found it to be $11.6 \%$ and not $4.5 \%$ ' ${ }^{77}$

In the end, it was not so much the establishment of standards for what good nutrition should consist of that changed in the postwar period, since international organizations, colonial administrations, and African trade unions appealed to tenets of nutritional science that had hardly changed since the 1930s. Rather, what differed was how these numerical standards were used, and the meaning attached to them. Whether at the level of international organizations or at that of the colonies, these figures became vectors of a relative measure of living standards in a world that was increasingly calibrated according to common criteria.

\section{Figures on hunger and malnutrition}

It was in this postwar context of comparison that the first important study was carried out evaluating the diets of people in French Africa based on field surveys across AOF. Such investigations revealed a degree of ambivalence: while establishing a corpus of new figures, they were riddled with a differentialist perspective that questioned the data's comparability. Nevertheless, they painted a new picture of hunger and malnutrition in French Africa. Though these studies did not change practice significantly, they did highlight the relative poverty of the populations as compared to universal norms.

In July 1945, the Colonial Secretary established an 'Investigative Commission for the Anthropological Study of Indigenous Peoples (Food and Nutrition)'. Commonly known as the 'Anthropological Mission', it had the explicit goal of increasing knowledge about food conditions in Africa and meeting France's prior commitments made at the Hot Springs conference. ${ }^{78}$ This commission was initially comprised of a doctor, a chemist, a psychologist, a home economics teacher, a secretary, two technical assistants in charge of food surveys, and a driver. ${ }^{79}$ It was under the direction of Léon Pales, a former colonial physician, who became a professor of anatomy and

\footnotetext{
76 CAOM GG-AEF-1H103-105, Inspection générale du travail du Moyen-Congo, 'Note sur la ration prévue à l'école de police de Brazzaville', 25 octobre 1950.

77 ANS 1H90, lettre du docteur Raoult à l'inspecteur général du travail et des lois sociales de l'AOF, 31 mars 1954.

78 ANS 1H92, ministère des Colonies, décision du 9 juillet 1945.

${ }^{79}$ ANS 1H92, Mission anthropologique, 'Rapport nº 1', 1945.
} 
anthropology at the Marseille School for the Health of Colonial Troops, and subsequently the assistant director of the Museum of Man in Paris. Between 1945 and 1948, this team traveled more than 20,000 kilometers in Senegal, French Sudan, Upper Volta, Guinea, and Côte d'Ivoire. Equipped with anthropometric measurement tools, its members studied 139 populations, recorded 546,770 measurements, and took 2,000 photographs of individuals. They also performed 65 autopsies and dissected 26 bodies. ${ }^{80}$ Certain tests were conducted using specialized tools, such as the Benedict device that measured the basal metabolic rate or the Meunier electrophotometer which detected vitamin deficiencies. They took blood samples to detect any carbohydrate, iron, and calcium deficiencies. In total, the commission conducted 502 food surveys in the territories they covered. This included a survey that involved spending a week with a family and weighing the food that comprised their meals. ${ }^{81}$-The objective was to "quantify the visible dietary intakes of several populations in AOF' and 'concretize known or suspected deficiencies by assigning them numerical values' ${ }^{82}$

This research produced a large set of figures about the nutritional intake of these populations. Based on this dataset, the Anthropological Mission distinguished between two categories of nutritional issues: first, chronic qualitative deficiencies, such that 'the populations of the whole territory do not have, consistently, the benefit of a balanced diet'; second, short-term quantitative insufficiencies which, during the lean season, affected ' $40 \%$ of individuals' ${ }^{83}$ Though these two findings were not new to the colonial administration, their conversion into hard numbers illustrated a reality that had been heretofore unimaginable: Léon Pales explained that 'the staff in charge of the calculations was so surprised that they had to stop in the middle of their work.' In some surveyed groups, such as people in a Malian village, consumption barely reached 800 calories during the lean season. Léon Pales elaborated:

It is hardly conceivable that two-thirds of the population of this village consumes between 158 and 964 calories per person per day, which comes to an average of 801 calories. These are all famine rations which we could barely dare to imagine. These are, however, the rations we saw prepared for the people present at the time of the survey and for those returning from the fields at dusk. During the eight days we stayed in the village and studied it, this remained consistent. ${ }^{84}$

\footnotetext{
${ }^{80}$ ANS 1H89, Mission anthropologique, 'Anthropologie des populations de l'AOF - Anthropologie des parties molles', 1948.

${ }^{81}$ Archives de l'Office du Niger, Ségou (AON) S0166, 'Bilan de la mission anthropologique de l'AOF (janvier 1946août 1948)', 1948.

${ }^{82}$ CAOM 1AFFPOL346, Mission anthropologique de l'AOF, 'Rapport du médecin lieutenant-colonel Pales', octobre 1948.

${ }^{83}$ Inter-African Conference, 152.

84 AON S0166, 'Bilan'.
} 
Admittedly, those who designed these studies were themselves skeptical of the reliability of their numerical findings. Léon Pales stated that the investigators only considered the visible dietary intakes and that meals would likely have been supplemented by other foods consumed outside the surveyors' purview. But regardless of their veracity, these figures still provided a new statistical outline of chronic malnutrition and seasonal under-nourishment. They also measured, for the first time, significant disparities between populations: nutritional issues appeared to be more prevalent in rural areas than in cities and to affect certain subsets of the population more acutely, such as pregnant or breastfeeding women, almost all of whom experienced significant nutritional deficiencies. Moreover, some territories were more affected than others. Léon Pales mentioned 'the Fouta Djalon [in Guinea] and Upper Volta' as 'two particularly deprived regions'. These sorts of statements, in turn, signaled a new way of distinguishing degrees of poverty between the colonies, by relying on nutritional statistical investigations. ${ }^{85}$

Running counter to this comparative perspective, the work of the Anthropological Mission revealed a differentialist perspective which vested the category of race with potential explanatory value. Finding it paradoxical that the deficiencies were not apparent on the individual level, Léon Pales expressed the possibility that 'the black body does not work like ours'. This explanation was given in particular with regards to carbohydrates, because of the elevated levels of hypoglycemia 'as compared to the normal levels in Europe', as well as for mineral salts, the need for which appeared 'applicable to all of humanity, once racial aspects have been accounted for' ${ }^{86}$ If, at each instance the Anthropological Mission concluded by rejecting this racial hypothesis, it was only after their investigations, as if the fact that race did not interfere with diet needed to be empirically demonstrated for each specific nutritional component. To question 'the origin of the high prevalence of hypoglycemia among blacks in AEF and AOF', Léon Pales compared the blood samples of African soldiers fed appropriately and individuals 'of the same race' who remained in their village, before finding that only the latter had abnormally low rates. This method led Pales to conclude:

It therefore appears that, in this regard, physiology is 'one'. The deficiencies that we have observed among Africans are due to an inadequate or imbalanced diet. They are ethnic and non-racial; instead, they are related to the way they live. ${ }^{87}$

The results of the Anthropological Mission surveys circulated among the new international organizations at the Inter-African Food Conference in Dschang in 1949, where they were compared to the new optimal ration standards recently set by the FAO, as well as used in the 'periodic reports on underdeveloped countries' sent to the UN. ${ }^{88}$ These surveys, alongside those

\footnotetext{
85 Ibid.

${ }^{86}$ Institut de médecine tropicale du service de santé des armées, Marseille (IMTSSA) 398, Mission anthropologique, 'Le problème des sels alimentaires en AOF', 1950.

${ }^{87}$ AON S0166, 'Bilan'.

${ }^{88}$ Conférence interafricaine, 278; CAOM 1AFFPOL947, Direction générale de la santé publique de l'AOF, 'Rapport sur l'hygiène et la santé publique en AOF. Documentation destinée à l'ONU', 1950.
} 
conducted at the same time in other African territories, contributed to international organizations' increasingly close association between the African continent and the problems of hunger and malnutrition ${ }^{89}$ In 1947, the FAO's first report on the topic of 'The State of Food and Agriculture,' focused on Europe and Asia, where there was an urgent need to increase 'the dietary standards of hundreds of millions who have not at any time had more than 2000 to 2200 calories'. This need was considered to be much more urgent and of a greater magnitude than that of Africa, considered to be a 'safety-valve for relieving the growing pressure of the world's population upon the world food supply'. ${ }^{90}$ Four years later, FAO's annual report used a very different tone when discussing the African continent:

Although data on food supplies for human consumption are extremely scarce, it appears from the available information that the African diet is often seriously deficient in calories, proteins and other nutrients. [...] The lack of protein is one of the most serious deficiencies in the diet of Africans. It is directly connected to the wide prevalence of a serious symptom of malnutrition called 'kwashiorkor' which was largely responsible for the high mortality rate among children from 6 months to 5 years of age. ${ }^{91}$

And yet, such an evolution cannot be explained entirely by the production of a new statistical knowledge on the nutritional conditions of the African populations: if we consider the emblematic case of kwashiorkor, its first numerical descriptions, as fragmentary as they were, were almost twenty years old by the time this FAO report was released..$^{92}$ More than the mere existence of this knowledge, therefore, it was its diffusion and use as a measurement that could be compared to universal norms, which explain how it became the definitive proof of hunger, malnutrition, and poverty.

The newly amplified meaning of this statistical knowledge did not, however, spur the establishment of a policy specifically designed to combat hunger and malnutrition in French Africa. The colonial authorities' main response to the Anthropological Mission's statistical table was a policy to increase food production. The governors highlighted, a few years later, the extension of the rice fields (to 'balance on-site production and consumption of carbohydrates'), the intensive cultivation of peanuts ('for lipids'), or the development livestock and the fishery ('for protein'). ${ }^{93}$ The French Minister of Overseas Territories, for his part, noted the 'insufficiency of

\footnotetext{
89 'Bibliographie sur l'alimentation et la nutrition en Afrique noire', Conférence interafricaine, 491-531.

${ }^{90}$ FAO, The State of Food and Agriculture: 1947 (Geneva, 1947), IV and 8.

${ }^{91}$ FAO, The State of Food and Agriculture: 1951 (Roma, 1951), 32-33.

${ }^{92}$ In her 1935 article, Cicely Williams evaluated the mortality rate of children with kwashiorkor in Gold Coast at 90 per cent, while mentioning other similar studies in East and South Africa. 'Kwashiorkor', 1151. Three years later, she estimated that 'probably less than 50 per cent of the babies born alive survive to maturity' in the Gold Coast. 'Child Health in the Gold Coast', Lancet, 231 (1938), 97.
} ${ }^{93}$ ANS 1H90, Inspection générale de la Santé publique de l'AOF, 'Notes sur les éléments susceptibles d'être fournis
pour la composition du rapport annuel sur l'agriculture et l'alimentation du comité français de la FAO', 1951. 
nitrogenous foods' and 'various mineral deficiencies' in the 'diet of continental Africa', advocated increasing the available protein options through animal husbandry and fishing, and developing the production of salt in AOF 'where, according to the work of Dr. Pales, $8 \%$ of the population has goiter, a disease caused by the lack of sodium chloride in their diet' ${ }^{94}$

Rarely, however, were measures aimed directly at undernourished or malnourished people. The AOF government recommended working on 'supplementing the feeding of infants and pregnant or lactating women', and 'creating school cafeterias [...] where medical inspections have shown that students were the most undernourished'. ${ }^{95}$ But these recommendations had little effect. The main intervention in this area was undertaken in Senegal. In light of the fact that the majority of children under five years old suffered from nutritional deficiencies, the colonial administration set up, from 1952 onwards on an experimental basis, the systematic distribution of powdered milk within several villages surrounding Dakar. This program was extended to several villages in Upper Volta the following year and resulted in the design of an 'Operational plan for a project to combat malnutrition and undernutrition among vulnerable groups in AOF'.${ }^{96}$ Due to lack of funding, however, this plan was never implemented. ${ }^{97}$

As has been demonstrated, the studies conducted on nutritional conditions in the aftermath of the Second World War, while not resulting in significant changes in practice, had the essential effect of translating into numerical terms the degree of hunger in French Africa and, by extension, of presenting these figures as proof that poverty in these territories existed to a greater extent compared to the rest of the world. In 1950, the Independent Union of Overseas Territories, one of the two main parliamentary groups that sent African deputies to the French National Assembly, referred to the 'mission led by Dr. Pales' to denounce 'how living standards of some French West African populations [we]re low', with 'daily rations often totaling less than 2,000 calories' ${ }^{98}$ Taken together with other statistics, the nutritional figures had become a technical, as well as a political, means of expressing poverty by the beginning of the mid-twentieth century.

\footnotetext{
${ }^{94}$ CAOM 2FIDES766, ministère de la France d'outre-mer, Direction de la Santé, 'Les problèmes alimentaires et nutritionnels en Afrique noire', 1952.

95 ANS 1H90, Inspection générale de la Santé publique de l'AOF, 'Réponse au questionnaire du 20 avril 1951 sur l'agriculture et l'alimentation', 1951.

${ }^{96}$ CAOM 2FIDES766, Ministère de la France d'outre-mer, Direction de la Santé, 'Les problèmes de la sousnutrition et de la malnutrition', 1955.

${ }^{97}$ J.-H. Jézéquel, “Le Lait qui soigne”" : tâtonnements thérapeutiques, réforme de l'État et déploiement des institutions internationales en Afrique Occidentale Française (1950-1960)' (unpublished paper, Colloque 'Lutter contre la faim en Afrique', Bordeaux, 2013).

${ }^{98}$ CAOM 1AFFPOL2257 'Journées d'étude des indépendants d'Outre-mer', juillet 1950.
} 


\section{CONCLUSION}

In this article, I have been concerned with ration statistics not for what they say about reality, but rather for what contemporaries understood them to mean. In so doing, I have also questioned the analytical framework for comprehending 'poverty in Africa' before it became a commonplace conception. From this line of questioning three final points emerge.

First, to conceive of poverty in the world presupposes a conception of a single world in which social, health, nutritional, and other realities are understood within a single referential framework. This, in turn, presupposes a commensurability of realities that should not be understood as preordained, but were rather the result of a social process that is both technical and political. ${ }^{99}$ I have demonstrated that these figures played an important role in the gradual recategorization of distant realities into relations of equivalency. Starting from the mid-twentieth century, statistics on food and nutrition came to be used as proof of disparities in living conditions between Africa and the rest of the world.

However, as I have emphasized, the mere existence of these figures did not necessarily lead to comparison. Indeed, in the 1920s and 1930s, there already existed food and nutrition statistics from French Africa which indicated the prevalence of hunger and malnutrition, but whose function, from the point of view of their contemporaries, was not to compare living conditions. Similar conclusions can be drawn by analyzing other measurements. Thus in the late 1920 s the first surveys of infant mortality were conducted in French Africa. ${ }^{100}$ But whereas infant mortality had been invoked since the previous century in industrialized societies to evaluate working-class living conditions, this was not the meaning initially assigned to them in Africa. ${ }^{101}$ Instead, until the late 1930s, the colonial administration was largely concerned with infant mortality because it 'slow[ed] population growth' and indicated the 'poor performance of [colonial] health services'. ${ }^{102}$ It was only after the war that infant mortality was reinterpreted as a sign that poverty in Africa was more pronounced than the rest of the world. ${ }^{103}$ It was also not until the postwar era that other figures such as production statistics came to be used to compare standards of living across various populations. This had not been the case between the wars, despite the fact that their calculation

\footnotetext{
${ }^{99}$ W. N. Espeland and M. Stevens, 'Commensuration as a Social Process', Annual Review of Sociology, 24 (1998), 313-343.

${ }^{100}$ A. Thiroux, 'La natalité et la mortalité infantile dans les colonies françaises', Revue philanthropique, 51-408, 1931, 561-569; G. Lefrou et M. Allard, 'Une décade démographique à Saint-Louis: Natalité, mortalité généerale, mortinatalité, mortalité infantile, Annales de medicine et de pharmacie coloniales, 30, 1932, 406-427.

101 Poverty: A Study of Town Life, xvi.

${ }^{102}$ ANS 2G39.9. Inspection générale des services sanitaires et médicaux de l'AOF, rapport annuel, 1939.

103 The first assessment of infant mortality at the scale of a French colony in Africa was conducted in Guinea in 1954. According to findings of the survey, 'a newborn child who has a fifty per cent chance of living beyond 30 years old in Guinea has the same chance of living longer than 70 years in France'. CAOM 2FIDES766, Gouvernement de la Guinée, 'Enquête démographique par sondage', premier fascicule, 1954.
} 
was already the object of meticulous - albeit not particularly reliable — accounting on the part of the colonial administration. ${ }^{104}$

In the end, all of these developments lead to the denial of any inherent causal value associated with the forms of knowledge that this article has just historicized: if these figures came to signify the poverty of African populations, it was not because of the figures themselves, as if they had unveiled a reality that had, until now, been overlooked. It was, instead, because they existed in an evolving political context that changed their meaning. It is possible, and even probable, that these figures did not conform to reality. But whatever their reliability, regardless of the extent to which they corresponded to local perceptions, these numbers did - as they were understood and used by their contemporaries in the mid-twentieth century - nonetheless contribute to the inclusion of African people in a singular world where it became possible to conceive of a state of poverty in contrast to a state of wealth.

104 On the changing meanings of production statistics in colonial and independent Africa see, V. Bonnecase, 'Généalogie d'une évidence statistique. De la "réussite" économique du colonialisme tardif à la "faillite" des Etats africains (v.1930-v. 1980)', Revue d'histoire moderne et contemporaine, 62:4 (2015), 33-63. 
